\title{
Snake assemblage of Ilha de São Sebastião, southeastern Brazil: comparison to mainland
}

\author{
Fernanda da Cruz Centeno ${ }^{1,2}$, Ricardo Jannini Sawaya ${ }^{1}$ \& Otavio Augusto Vuolo Marques ${ }^{1}$ \\ ${ }^{1}$ Laboratório Especial de Ecologia e Evolução, Instituto Butantan, \\ Av. Doutor Vital Brasil, 1500, CEP 05503-900, São Paulo, SP, Brazil, http://www.butantan.gov.br/ecoevo \\ ${ }^{2}$ Corresponding author: Fernanda da Cruz.Centeno, e-mail: fccenteno@yahoo.com.br
}

CENTENO, F.C., SAWAYA, R.J. \& MARQUES, O.A.V. 2008. Snake assemblage of Ilha de São Sebastião, southeastern Brazil: comparison to mainland. Biota Neotrop. 8(3): http://www.biotaneotropica.org.br/v8n3/ en/abstract?article+bn00608032008.

\begin{abstract}
We provide a checklist of snake species from Ilha de São Sebastião (Ilhabela), the largest coastal island in Brazil located on the northern coast of São Paulo state. We also compare snake diversity (including richness and relative abundance of species) of Ilhabela and the nearest mainland municipality, São Sebastião. We obtained the data from the herpetological collections of the Instituto Butantan and Museu de Zoologia of Universidade de São Paulo, including records from 1939 to 2005 . We recorded twenty snake species from Ilhabela ( $\mathrm{N}=376$ individuals), and the dominant species was the viperid Bothrops jararaca with 55\% of dominance. In São Sebastião we recorded 27 species $(\mathrm{N}=625)$, and Bothrops jararaca was also the dominant species, but with $25 \%$ of dominance. Some common species seem to be more abundant in the mainland. Even considering the different number of individuals sampled between localities, rarefactions curves and richness estimations confirm that São Sebastião should present a higher number of species. The Chao 1 estimates 20 species (19 to $21 \mathrm{spp}$.) for Ilhabela, and 32 species (27 to 37 spp.) for São Sebastião. One of the most distinctive aspects of the snake fauna of Ilhabela is the occurrence of four species of the genus Dipsas (D. albifrons, D. alternans, D. neivai, and $D$. petersi). Throughout most of the coastal Atlantic Forest of São Paulo state only D. petersi is recorded. This is the first assessment of diversity of snakes in Ilha de São Sebastião and the municipality of São Sebastião. Thus, it is a contribution to the knowledge and conservation of the herpetofauna of the region and of the Atlantic Forest of southeastern Brazil.
\end{abstract}

Keywords: snakes, island, diversity, richness, dominance, Atlantic Forest.

CENTENO, F.C., SAWAYA, R.J. \& MARQUES, O.A.V. 2008. Taxocenose de serpentes da Ilha de São Sebastião, sudeste do Brasil: comparação com o continente. Biota Neotrop. 8(3): http://www.biotaneotropica. org.br/v8n3/pt/abstract?article+bn00608032008.

Resumo: Apresentamos uma lista de espécies de serpentes da Ilha de São Sebastião (Ilhabela), maior ilha continental do Brasil localizada no litoral norte do estado de São Paulo. Comparamos a diversidade de serpentes (incluindo riqueza e abundância relativa de espécies) entre Ilhabela e São Sebastião, o município mais próximo no continente. Obtivemos os dados a partir das coleções herpetológicas do Instituto Butantan e Museu de Zoologia da Universidade de São Paulo, incluindo registros de 1939 a 2005. Registramos vinte espécies de serpentes em Ilhabela ( $\mathrm{N}=376$ indivíduos), e a espécie dominante foi o viperídeo Bothrops jararaca com 55\% de dominância. Em São Sebastião registramos 27 espécies ( $\mathrm{N}=625)$, e Bothrops jararaca também foi a espécie dominante, mas com 25\% de dominância. Por outro lado, algumas espécies comuns parecem ser mais abundantes no continente. Mesmo considerando o número diferente de indivíduos amostrados entre as localidades, curvas de rarefação e estimativas de riqueza confirmam que São Sebastião deve apresentar um maior número de espécies. Chao 1 estimou 20 espécies (19 a 21 spp.) para Ilhabela e 32 espécies (27 a 37 spp.) para São Sebastião. Porém, um dos aspectos que mais diferenciam a fauna de serpentes de Ilhabela é a ocorrência de quatro espécies do gênero Dipsas (D. albifrons, D. alternans, D. neivai, e D. petersi). Ao longo da maior parte do litoral da Mata Atlântica costeira do estado de São Paulo apenas D. petersi é registrada. Esta é a primeira avaliação da diversidade da fauna de serpentes da Ilha de São Sebastião e do município de São Sebastião. Desta forma, este estudo contribui para o conhecimento e conservação da herpetofauna da região assim como da Mata Atlântica do sudeste do Brasil.

Palavras-chave: serpentes, ilha, diversidade, riqueza, dominância, Mata Atlântica. 


\section{Introduction}

The snake fauna of the Neotropical region is characterized by high species richness and complexity of ecological relationships among species (Duellman 1978, Henderson et al. 1979, Vitt 1987). Nevertheless, patterns of snake natural history and ecology in this region remain poorly known. Even basic information on snakes in many regions of Brazil is scarce or nonexistent (Sazima \& Haddad 1992). This is particularly true regarding basic information on natural history data for snakes of the Atlantic Forest of southeastern Brazil, although species composition for this region is relatively well described (cf. Marques et al. 2001).

The Atlantic Forest presents high biological diversity with great number of endemic species (Lino 1992) and it is among the most threatened biodiversity hotspots in the world (Myers et al. 2000). Despite this, the region continues to suffer severe anthropogenic pressure, risking imminent extinction of the remaining species (Morellato \& Haddad 2000).

Information on island faunas of southeastern Brazil is scarce and generally restricted to partial species lists (Vanzolini 1973, Sawaya 1999, Cicchi et al. 2007). The Ilha de São Sebastião is the largest continental island in the Brazilian coast. It remains poorly known despite few faunal surveys that have been conducted there. Ihering (1897) listed only two species of snakes, and Luederwaldt (1929) reported three additional species for the island. Müller (1968) recorded eight more species of snakes for the island. Thus, until recently, 13 snake species have been recorded in Ilha de São Sebastião. We present an updated checklist of snakes from Ilha de São Sebastião based on records from the main two herpetological collections in southeastern Brazil. To compare the island and continental faunas in this region, we also present a checklist of the adjacent mainland snake fauna, from the municipality of São Sebastião (Figure 1), hereafter referred as São Sebastião.

\section{Materials and Methods}

\section{Study site}

The Ilha de São Sebastião, municipality of Ilhabela (hereafter referred Ilhabela; Figure 1) is a large island (ca. $336 \mathrm{~km}^{2}$ ) located on the north coast of São Paulo state $\left(23^{\circ} 45^{\prime}\right.$ to $23^{\circ} 55^{\prime} \mathrm{S}$ and $45^{\circ} 17^{\prime}$ to $45^{\circ} 24^{\prime} \mathrm{W}$ ). It is only ca. $2 \mathrm{~km}$ from the mainland, municipality of São Sebastião (ca. $401 \mathrm{~km}^{2}$ ), and the depth in São Sebastião ocean channel is up to $46 \mathrm{~m}$ (Vanzolini 1973, Ângelo 1989). The

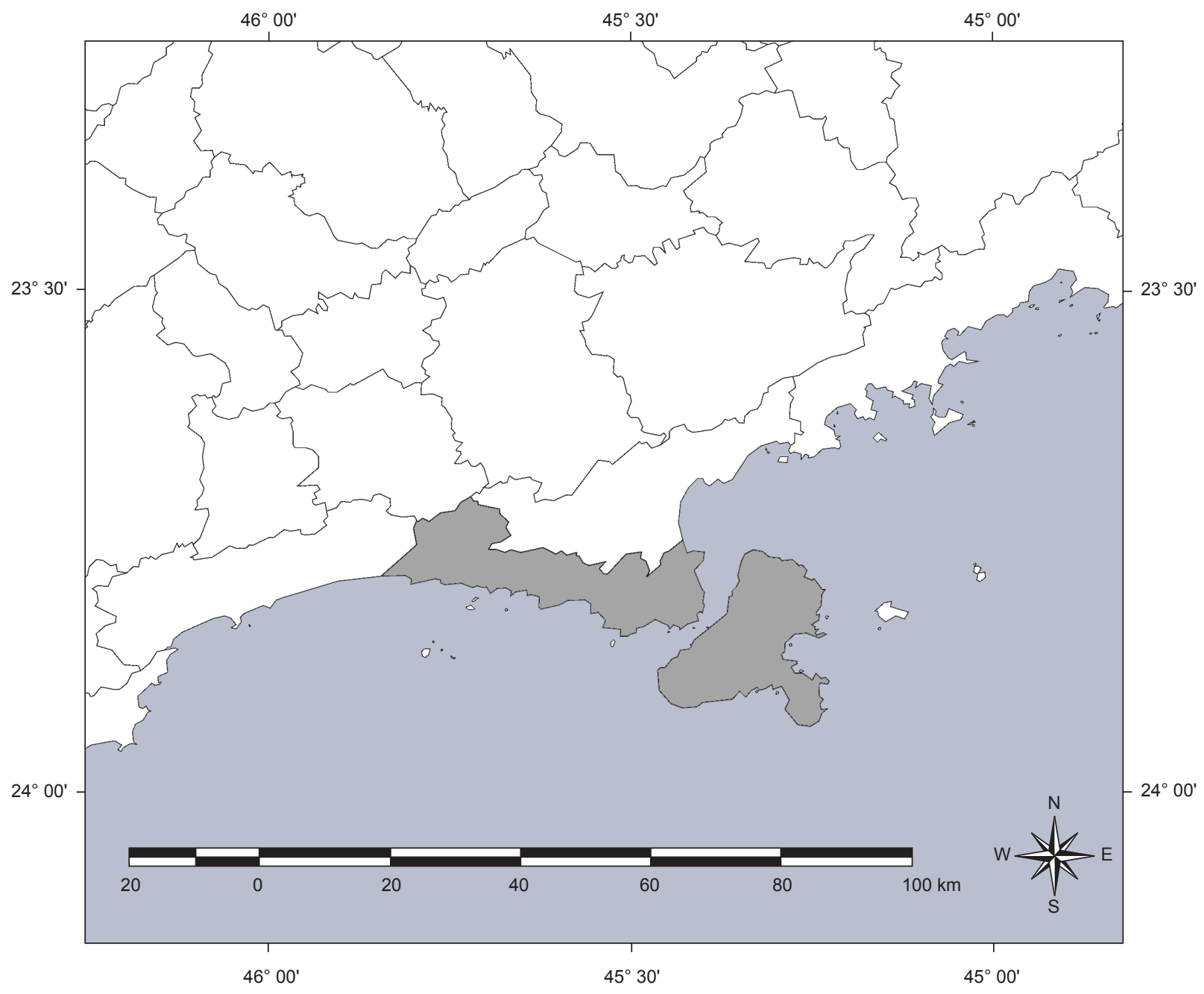

Figure 1. Northern coast of São Paulo state, southeastern Brazil. Ilha de São Sebastião (Ilhabela) and municipality of São Sebastião (São Sebastião) in gray. Figura 1. Litoral norte do estado de São Paulo, sudeste do Brasil. Ilha de São Sebastião (Ilhabela) e município de São Sebastião (São Sebastião) em cinza. 
island was probably separated from the mainland at the end of the Quaternary, about 10.000 to 12.000 years ago (Milliman \& Emery 1968, Vanzolini 1973). The area is located within the Atlantic Forest Domain, characterized by the high species diversity and endemism (Müller 1968, Lino 1992). The island is fairly mountainous with the highest peak reaching $1379 \mathrm{~m}$ (França 1954). The climate presents a mean temperature of $22{ }^{\circ} \mathrm{C}$, and around $1500 \mathrm{~mm}$ of annual rainfall (Olmos 1996, Milanesi 2007).

\section{Data collection}

We obtained records of snake species in the herpetological collections of the Instituto Butantan (IBSP) and Museu de Zoologia of
Universidade de São Paulo (MZUSP). We included all preserved specimens from Ilhabela and São Sebastião deposited in both collections from 1939 to 2005 . We confirmed the identifications of all preserved specimens. Additionally, we included specimens received by the Laboratório de Herpetologia of IBSP, from March 1983 to March 2002, without voucher specimens, for estimating the relative abundance of species. Six species (out of 27) recorded from São Sebastião were only registered and do not have voucher specimens (Table 1).

\section{Data analysis}

Species richness of Ilhabela and São Sebastião were compared by rarefaction curves (sensu Gotelli \& Colwell 2001) generated in

Table 1. Species list of snakes from Ilha de São Sebastião (Ilhabela; island) and municipality of São Sebastião (São Sebastião; mainland). Specimens deposited: specimens deposited in IBSP and MZUSP from 1939 to 2005. Specimens recorded: specimens received by the Laboratório de Herpetologia of IBSP, from March 1983 to March 2002, without voucher specimens. Number of individuals (N) and percentage of the total number of individuals (\%).

Tabela 1. Lista de espécies de serpentes da Ilha de São Sebastião (Ilhabela; ilha) e município de São Sebastião (São Sebastião; continente). Indivíduos depositados: indivíduos depositados no IBSP e MZUSP entre 1939 e 2005. Indivíduos registrados: indivíduos recebidos pelo Laboratório de Herpetologia do IBSP, de Março de 1983 a Março de 2002, sem espécimes testemunho. Número de indivíduos (N) e porcentagem em relação ao número total de indivíduos (\%).

\begin{tabular}{|c|c|c|c|c|c|c|c|c|}
\hline \multirow[t]{3}{*}{ Family/Species } & \multicolumn{4}{|c|}{ Specimens deposited } & \multicolumn{4}{|c|}{ Specimens recorded } \\
\hline & \multicolumn{2}{|c|}{$\begin{array}{l}\text { Ilhabela } \\
\text { (island) }\end{array}$} & \multicolumn{2}{|c|}{$\begin{array}{c}\text { São Sebastião } \\
\text { (mainland) }\end{array}$} & \multicolumn{2}{|c|}{$\begin{array}{l}\text { Ilhabela } \\
\text { (island) }\end{array}$} & \multicolumn{2}{|c|}{$\begin{array}{c}\text { São Sebastião } \\
\text { (mainland) }\end{array}$} \\
\hline & $\mathbf{N}$ & $(\%)$ & $\mathbf{N}$ & $(\%)$ & $\mathbf{N}$ & $(\%)$ & $\mathbf{N}$ & $(\%)$ \\
\hline \multicolumn{9}{|l|}{ BOIDAE } \\
\hline Corallus hortulanus (Linnaeus 1758) & - & - & 7 & 3,0 & - & - & 3 & 0,5 \\
\hline \multicolumn{9}{|l|}{ COLUBRIDAE } \\
\hline Chironius bicarinatus (Wied 1820) & 4 & 1,9 & 5 & 2,1 & 13 & 3,5 & 17 & 2,7 \\
\hline Chironius exoletus (Linnaeus 1758) & - & - & 8 & 3,4 & - & - & 5 & 0,8 \\
\hline Chironius foveatus Schmidt \& Walker, 1943 & 2 & 0,9 & 13 & 5,5 & 1 & 0,3 & 2 & 0,3 \\
\hline Chironius fuscus (Linnaeus 1758) & - & - & 11 & 4,7 & - & - & 5 & 0,8 \\
\hline Chironius laevicollis (Wied 1824) & 3 & 1,4 & 7 & 3,0 & 5 & 1,3 & 9 & 1,4 \\
\hline Clelia plumbea (Wied 1820) & 5 & 2,3 & 3 & 1,3 & 2 & 0,5 & 6 & 1,0 \\
\hline Dipsas albifrons (Sauvage 1884) & 1 & 0,5 & - & - & 1 & 0,3 & - & - \\
\hline Dipsas alternans (Jan 1863) & 1 & 0,5 & - & - & 1 & 0,3 & - & - \\
\hline Dipsas neivai Amaral, 1926 & 3 & 1,4 & - & - & 2 & 0,5 & - & - \\
\hline Dipsas petersi Laurenti, 1768 & 2 & 0,9 & - & - & 3 & 0,8 & - & - \\
\hline Echinanthera cephalostriata Di-Bernardo, 1996 & 2 & 0,9 & 1 & 0,4 & 2 & 0,5 & 1 & 0,2 \\
\hline Echinanthera undulata (Wied 1824) & - & - & 7 & 3,0 & - & - & 3 & 0,5 \\
\hline Erythrolamprus aesculapii (Linnaeus 1766) & 2 & 0,9 & 6 & 2,5 & 2 & 0,5 & 1 & 0,2 \\
\hline Liophis miliaris (Linnaeus 1758) & 2 & 0,9 & 11 & 4,7 & 9 & 2,4 & 56 & 9,0 \\
\hline Mastigodryas bifossatus (Amaral 1934) & - & - & - & - & - & - & 1 & 0,2 \\
\hline Oxyrhopus clathratus Duméril, Bibron \& Duméril 1854 & 6 & 2,8 & - & - & 2 & 0,5 & - & - \\
\hline Oxyrhopus guibei (Hoge \& Romano 1977) & - & - & - & - & - & - & 3 & 0,5 \\
\hline Philodryas patagoniensis (Girard 1858) & & & & & & & 1 & 0,2 \\
\hline Sibynomorphus neuwiedi (Iherinhg 1910) & 9 & 4,2 & 4 & 1,7 & 31 & 8,2 & 11 & 1,8 \\
\hline Siphlophis pulcher Raddi, 1820 & 4 & 1,9 & 5 & 2,1 & 2 & 0,5 & 4 & 0,6 \\
\hline Spilotes pullatus (Linnaeus 1758) & 5 & 2,3 & 3 & 1,3 & 7 & 1,9 & 18 & 2,9 \\
\hline Thamnodynastes cf. nattereri (Mikan 1820) & 12 & 5,6 & 9 & 3,8 & 18 & 4,8 & 3 & 0,5 \\
\hline Tomodon dorsatus Duméril \& Bibron 1853 & - & - & - & - & - & - & 1 & 0,2 \\
\hline Tropidodryas serra Schlegel 1837 & - & - & 5 & 2,1 & - & - & 17 & 2,7 \\
\hline Tropidodryas striaticeps (Cope 1870) & - & - & - & - & - & - & 7 & $\overrightarrow{1,1}$ \\
\hline Waglerophis merremi (Wagler 1824) & - & - & - & - & - & - & 1 & 0,2 \\
\hline Xenodon neuwiedii (Günther 1863) & 1 & 0,5 & 5 & 2,1 & 3 & 0,8 & 47 & 7,5 \\
\hline \multicolumn{9}{|l|}{ ELAPIDAE } \\
\hline Micrurus corallinus (Merrem 1820) & 20 & 9,4 & 54 & 22,9 & 40 & 10,6 & 122 & 19,5 \\
\hline \multicolumn{9}{|l|}{ VIPERIDAE } \\
\hline Bothrops jararaca (Wied 1824) & 100 & 46,9 & 39 & 16,5 & 207 & 55 & 157 & 25,1 \\
\hline Bothrops jararacussu Lacerda, 1884 & 29 & 13,6 & 32 & 13,6 & 25 & 6,6 & 123 & 19,7 \\
\hline Crotalus durissus (Linnaeus 1758) & - & - & 1 & 0,4 & - & - & 1 & 0,2 \\
\hline Total & 213 & 100 & 236 & 100 & 376 & 100 & 625 & 100 \\
\hline
\end{tabular}


EstimateS 7.5 (Colwell 2005), and by the species richness estimator Chao 1 (Chao 1987). We compare the dominance using the percentage of the most abundant species (Berger-Parker index). Because of the different number of individuals recorded in each locality (Ilhabela: $\mathrm{N}=376$; São Sebastião: $\mathrm{N}=625$ ), we calculated the expected species richness and dominance of São Sebastião for $\mathrm{N}=376$ by the rarefaction method (Sanders 1968) in EcoSim 7.0 (Gotelli \& Entsminger 2005), with 1000 iterations. The relative abundance of species between localities was compared visually by bar graphs. The distribution of relative abundance of species from Ilhabela and São Sebastião was compared by Kolmogorov-Smirnov test.

\section{Results and Discussion}

Twenty snake species were recorded from Ilhabela, and 27 were recorded from São Sebastião (Table 1). The higher richness observed in the mainland is correlated with the higher number of specimens recorded (Figure 2). The rarefaction curves of Ilhabela and São Sebastião (Figure 2) indicates that more species occur in both localities, and there are no significant differences in richness between localities for a similar number of specimens (see the standard deviation of São Sebastião curve for $\mathrm{N}=400$ ). However, the inclination of both rarefaction curves (Figure 2) indicates that Ilhabela must present lower species richness. Additionally, the rarefaction method (Table 2) indicates a higher richness for the mainland, when the same number of specimens is considered $(\mathrm{N}=376)$. The estimator of species richness Chao 1 also indicated a lower species richness for Ilhabela (estimated richness $S=20 \pm 1$ ) when compared to São Sebastião $(\mathrm{S}=32 \pm 5$; Table 2). Therefore, species richness of the island is likely smaller than that on the mainland, which is probably due to the insularization effects including the smaller area and isolation. Snake richness in other islands of São Paulo state is not well known, but Ilha dos Alcatrazes and Ilha da Queimada Grande islands have been studied regularly during the last ten years. Richness on islands decreases with smaller island size and the greater distance from the mainland (MacArthur \& Wilson 1967). We observed higher species richness in Ilhabela when compared to Ilha dos Alcatrazes and Ilha

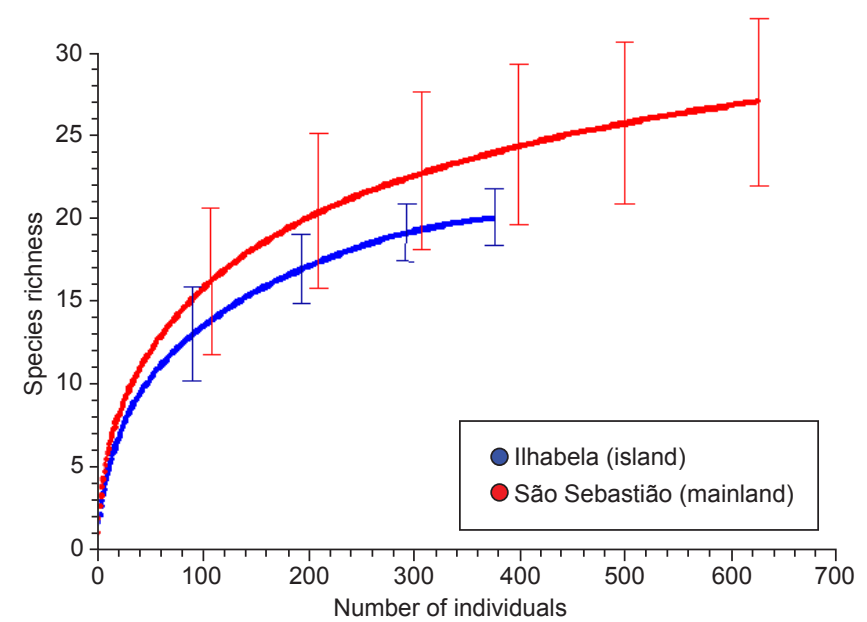

Figure 2. Rarefaction curves of Ilha de São Sebastião in blue (Ilhabela; island) and municipality of São Sebastião in red (São Sebastião; mainland) generated in EstimateS. Vertical bars correspond to standard deviations of observed species richness.

Figura 2. Curvas de rarefação da Ilha de São Sebastião em azul (Ilhabela; ilha) e município de São Sebastião em vermelho (São Sebastião; continente) geradas no EstimateS. Barras verticais correspondem ao desvio padrão da riqueza de espécies observada. da Queimada Grande, which had only four and two snake species, respectively (Sawaya, R.J. pers. obs.). The Ilha dos Alcatrazes is larger than Ilha da Queimada Grande, but both distances from the mainland are similar.

One of the most distinctive aspects of the snake fauna of Ilhabela is the occurrence of four species of the genus Dipsas (D. albifrons, $D$. alternans, D. neivai, and D. petersi; Table 1). With the exception of $D$. petersi, the three other species had never been recorded in lowlands throughout most of São Paulo state. Only a few records of D. albifrons, D. alternans and D. neivai in highlands of São Paulo state are available. Dipsas albifrons also occurs in Ilha dos Alcatrazes and Ilha da Queimada Grande. So, those continental islands could harbor relictual populations and/or species, as already suggested for frogs (Sawaya \& Haddad 2006).

The distribution of relative abundance was significant different among Ilhabela and São Sebastião (Kolmogorov-Smirnov, $\left.\mathrm{D}_{\max }=0.36 ; \mathrm{p}>0.05\right)$. The dominant species in both localities was Bothrops jararaca, a common species widespread throughout the Serra do Mar range. The dominance of vipers in Brazilian snake assemblages seems to be a common trend in the Serra do Mar (Marques 1998, Hartmann 2005). Thus, B. jararaca would be expected to be the dominant species in both localities. But despite the same dominant species, the values of dominance were much higher in the island $(55.0 \%)$ comparing to the mainland (25.1\%; Table 2; Figure 3$)$. The unequal number of specimens recorded in both localities did not affect the dominance, as the expected dominance for the mainland by the rarefaction method ( $\mathrm{N}=376$ individuals) was very similar to the observed dominance for $\mathrm{N}=625$ (Table 2). Species can be dominant in islands in many and unexpected ways, depending on the pressures exerted by competition, ecological plasticity, and/or colonizing success (see MacArthur \& Wilson 1967). Thus, the high dominance of $B$. jararaca in Ilhabela could be related to one or more of those factors. Those aspects could also influence the relative abundance of other species as Bothrops jararacussu and Micrurus corallinus, which seem to be relatively much more abundant in the mainland comparing to the island (Figure 3). However, even for those common species

Table 2. Number of individuals, observed richness, estimated richness (Chao 1), expected richness by rarefaction for $\mathrm{N}=376$ individuals, dominant species, observed dominance, and expected dominance by rarefaction for N = 376 individuals, of snakes from Ilha de São Sebastião (Ilhabela; island) and municipality of São Sebastião (São Sebastião; mainland), São Paulo state. In parenthesis, $95 \%$ confidence interval.

Tabela 2. Número de indivíduos, riqueza observada, riqueza estimada (Chao 1), riqueza esperada por rarefação para $\mathrm{N}=376$ indivíduos, de serpentes da Ilha de São Sebastião (Ilhabela; ilha) e município de São Sebastião (São Sebastião; continente), estado de São Paulo. Em parênteses, 95\% de intervalo de confiança.

\begin{tabular}{lcc}
\hline & $\begin{array}{c}\text { Ilhabela } \\
\text { (island) }\end{array}$ & $\begin{array}{c}\text { São Sebastião } \\
\text { (mainland) }\end{array}$ \\
\hline Number of individuals & 376 & 625 \\
Observed richness & 20 & 27 \\
$\begin{array}{l}\text { Estimated richness (Chao 1) } \\
\text { Expected richness } \\
\text { (rarefaction; } \mathrm{N}=376)\end{array}$ & $20(19-21)$ & $32(27-37)$ \\
$\begin{array}{l}\text { Dominant species } \\
\text { Observed dominance }\end{array}$ & - & $24(21-26)$ \\
$\begin{array}{l}\text { Expected dominance } \\
\text { (rarefaction; } \mathrm{N}=376)\end{array}$ & $55.0 \%$ & jararaca \\
\hline
\end{tabular}



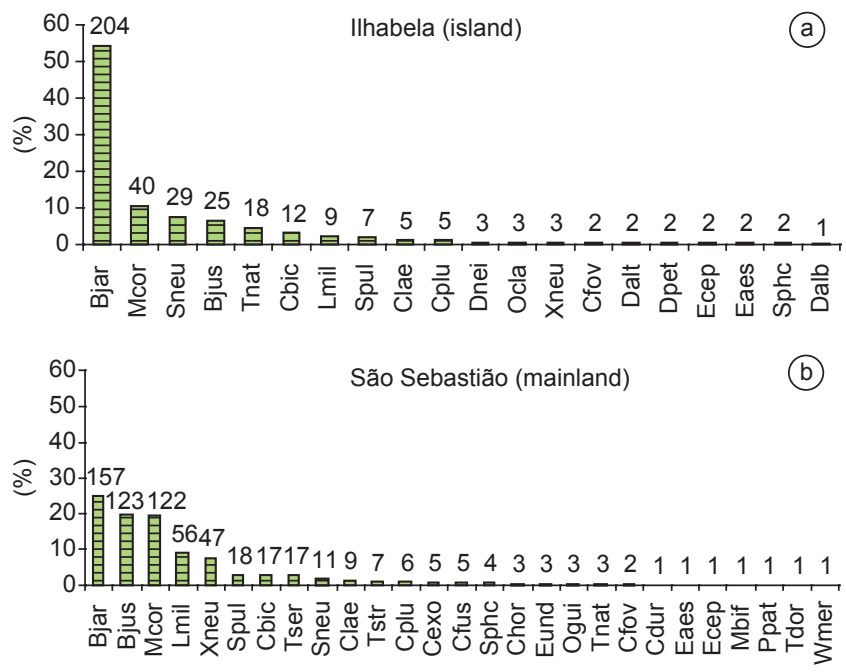

Figure 3. Relative abundance of snake species in percentage of the total number of individuals recorded in Ilha de São Sebastião (a - Ilhabela (island); total number of individuals $=376$ ), and municipality of São Sebastião (b - São Sebastião (mainland); total number of individuals $=625$ ) from specimens received by the Laboratório de Herpetologia of IBSP, from March 1983 to March 2002, without voucher specimens. The number of individuals for each species is indicated above each bar. Bjar $=$ Bothrops jararaca $;$ Bjus $=$ Bothrops jararacussu $;$ Cbic $=$ Chironius bicarinatus Cdur $=$ Crotalus durissus; Cexo $=$ Chironius exoletus $;$ Cfus = Chironius fuscus; Clae $=$ Chironius laevicollis $;$ Cfov $=$ Chironius foveatus $;$ Chor $=$ Corallus hortulanus $; \mathrm{Cplu}=$ Clelia plumbea $;$ Dalb $=$ Dipsas albifrons; Dalt $=$ Dipsas alternans $;$ Dnei $=$ Dipsas neivai $;$ Dpet $=$ Dipsas petersi $;$ Eaes $=$ Erythrolamprus aesculapi $;$ Ecep = Echinanthera cephalostriata , Eund = Echinanthera undulata $;$ Lmil $=$ Liophis miliaris; Mbif $=$ Mastigodryas bifossatus; Mcor = Micrurus corallinus; Ocla $=$ Oxyrhopus clathratus $;$ Ogui $=$ Oxyrhopus guibei ; Ppat = Philodryas patagoniensis $;$ Sneu = Sibynomorphus neuwiedi ; Sphc $=$ Siphlophis pulcher $;$ Spul $=$ Spilotes pullatus $;$ Tdor $=$ Tomodon dorsatus $;$ Tnat $=$ Thamnodynastes $\mathrm{cf}$. nattereri $;$ Tser $=$ Tropidodryas serra $; \mathrm{Tstr}=$ Tropidodryas striaticeps $;$ Wmer $=$ Waglerophis merremi $;$ Xneu $=$ Xenodon neuwiedii .

Figura 3. Abundância relativa de espécies de serpentes em porcentagem do número total de indivíduos registrados na Ilha de São Sebastião (a - Ilhabela (ilha); número total de indivíduos = 376), e no município de São Sebastião (b - São Sebastião (continente); número total de indivíduos $=625$ ) de espécimes recebidos pelo Laboratório de Herpetologia do IBSP, de Março de 1983 a Março de 2002, sem espécimes testemunho. O número de indivíduos de cada espécie é indicado acima de cada barra. Bjar = Bothrops jararaca Bjus $=$ Bothrops jararacussu $;$ Cbic $=$ Chironius bicarinatus $;$ Cdur $=$ Crotalus durissus $; \mathrm{Cexo}=$ Chironius exoletus $;$ Cfus $=$ Chironius fuscus $;$ Clae $=$ Chironius laevicollis $;$ Cfov $=$ Chironius foveatus $;$ Chor = Corallus hortulanus; Cplu $=$ Clelia plumbea $;$ Dalb $=$ Dipsas albifrons $;$ Dalt $=$ Dipsas alternans $;$ Dnei $=$ Dipsas neivai $;$ Dpet $=$ Dipsas petersi : Eaes $=$ Erythrolamprus aesculapi $;$ Ecep $=$ Echinanthera cephalostriata $;$ Eund = Echinanthera undulata $;$ Lmil $=$ Liophis miliaris $;$ Mbif $=$ Mastigodryas bifossatus; Mcor $=$ Micrurus corallinus; Ocla $=$ Oxyrhopus clathratus $;$ Ogui $=$ Oxyrhopus guibe $;$ Ppat $=$ Philodryas patagoniensis $;$ Sneu = Sibynomorphus neuwiedi $;$ Sphc $=$ Siphlophis pulcher $;$ Spul $=$ Spilotes pullatus $;$ Tdor $=$ Tomodon dorsatus $;$ Tnat $=$ Thamnodynastes $\mathrm{cf}$. natterer $;$; Tser $=$ Tropidodryas serra $; \mathrm{Tstr}=$ Tropidodryas striaticeps $;$ Wmer = Waglerophis merremi; Xneu $=$ Xenodon neuwiedii .

in Atlantic Forest of southeastern Brazil, information on natural history is limited. Further studies on ecology of snake species in those localities are still necessary for explaining the abundance patterns registered at Ilhabela and São Sebastião.

Intensive studies on Ilha de São Sebastião have not been carried out since the work of Müller (1968). The present study is the first detailed checklist of snakes presented for Ilha de São Sebastião and the municipality of São Sebastião. Thus, it is a contribution to the knowledge and conservation of the herpetofauna of Ilhabela and São Sebastião as well as the Atlantic Forest of southeastern Brazil.

\section{Acknowledgements}

We thank Francisco L. Franco and Hussan Zaher for permission to access the herpetological collections of Instituto Butantan and Museu de Zoologia da Universidade de São Paulo, respectively; Valdir J. Germano and Paulo J. P. Cicchi for valuable help during the laboratory work; Laurie Vitt and Cristiano Nogueira for critically reading and improving the manuscript.

\section{References}

ÂNGELO, S. 1989. Ilhas do Litoral Paulista, Série documentos. Secretaria do Meio Ambiente - SMA, São Paulo, 49p.

CHAO, A. 1987. Estimating the population size for capture-recapture data with unequal catchability. Biometrics 43(4):783-791.

CICCHI, P.J.P., SENA, M.A., PECCININI-SEALE, D.M. \& DUARTE, M.R. Serpentes das ilhas costeiras do estado de São Paulo, sudeste do Brasil. Biota neotrop. 7(2): http://www.biotaneotropica.org.br/v7n2/pt/ abstract?article+bn03907022007 (último acesso em 15/12/2007).

COLWELL, R.K. 2005. EstimateS: statistical estimation of species richness and shared species from samples. Version 7.5. Department of Ecology and Evolutionary Biology, U-43, University of Connecticut, Storrs, USA: http://viceroy.eeb.uconn.edu/estimates.htm (último acesso em 07/12/2005).

DUELLMAN, W.E. 1978. The biology of an equatorial herpetofauna in amazonian ecuador. Misc. publ. Univ. Kans. Mus. Nat. Hist. 65:1-352.

FRANÇA, A. 1954. A Ilha de São Sebastião: estudo de geografia humana. Faculdade de Filosofia, Ciências e Letras, Universidade de São Paulo. Boletim 178, Geografia n.10.

GOTELLI, N.J. \& COWELL, R.K. 2001. Quantifying biodiversity: procedures and pitfalls in the measurement and comparison of species richness. Ecol. Lett. 4(4):379-391.

GOTELLI, N.J. \& ENTSMINGER, G.L. 2005. EcoSim: Null models software for ecology. Version 7.0. Acquired Intelligence Inc. \& Kesey-Bear: http://homepages.together.net/ gentsmin/ecosim.htm. (último acesso em 10/12/2005).

HARTMANN, P.A. 2005. História natural e ecologia de duas taxocenoses de serpentes na Mata Atlântica. Tese de Doutorado, Universidade Estadual Paulista "Júlio de Mesquita Filho", Rio Claro.

HENDERSON, R.W., DIXON, J.R. \& SOINI, P. 1979. Resource partitioning in amazonian snake communities. Contrib. biol. geol. 22:1-11.

VON IHERING, H. 1897. A Ilha de São Sebastião. Rev. Mus. Pau. 2:129-171.

LINO, C.F. 1992. Reserva da biosfera da Mata Atlântica - Plano de ação, v.1, referências básicas. Consórcio Mata Atlântica/UNICAMP, Campinas.

LUEDERWALDT, H. 1929. Resultados de uma excursão científica à Ilha de São Sebastião no litoral do estado de São Paulo. Rev. Mus. Pau. 16:1-79.

MACARTHUR, R.H. \& WILSON, E.O. 1967. The theory of island biogeography. Princeton University Press, Princeton.

MARQUES, O.A.V. 1998. Composição faunística, história natural e ecologia de serpentes da Mata Atlântica, na região da Estação Ecológica JuréiaItatins, São Paulo, SP. Tese de Doutorado, Universidade de São Paulo, São Paulo.

MARQUES, O.A.V., ETEROVIC, A. \& SAZIMA, I. 2001. Serpentes da Mata Atlântica - Guia ilustrado para a Serra do Mar. Editora Holos, Ribeirão Preto.

MILANESI, M.A. 2007. Avaliação do efeito orográfico na pluviometria de vertentes opostas da Ilha de São Sebastião (Ilhabela, SP). Dissertação de Mestrado, Universidade de São Paulo, São Paulo. 
MILLIMAN, J.D. \& EMERY, K.O. 1968. Sea levels during the past 35.000 years. Science 6(162):1121-1123.

MORELLATO, P.C. \& HADDAD, C.F.B. Introduction: The Brazilian Atlantic Forest. Biotropica 32(4b Atlantic Forest Special Issue):786-792, 2000.

MÜLLER, P. 1968. Die herpetofauna der Insel von São Sebastião (Brasilien). Saarbrücken Zeitung, Verlag und Druckerei GmbH, Germany.

MYERS, N., MITTERMEIER, R.A., MITTERMEIER, C.G., DA FONSECA, G.A.B. \& KENT, J. 2000. Biodiversity hotspots for conservation priorities. Nature 403(6772):853-858.

OLMOS, F. 1996. Missing species in São Sebastião Island, southeastern Brazil. Pap. avulsos zool. 39(18):329-349.

SANDERS, H. 1968. Marine benthic diversity: a comparative study. Am. Nat. 102(925):243-282.

SAWAYA, R.J. 1999. Diversidade, densidade e distribuição altitudinal da anurofauna de serapilheira da Ilha de São Sebastião, SP. Dissertação de Mestrado, Universidade de São Paulo, São Paulo.
SAWAYA, R.J. \& HADDAD, C.F.B. 2006. Amphibia, Anura, Stereocyclops parkeri: distribution extension, new state record, geographic distribution map. Check List 2(3):74-76.

SAZIMA, I. \& HADDAD, C.F.B. 1992. Répteis da Serra do Japi: notas sobre história natural. In História natural da Serra do Japi: ecologia e preservação de uma área florestal no sudeste do Brasil (L.P.C. Morellato, ed.). Editora da Unicamp/FAPESP, São Paulo, p.212-236.

VANZOLINI, P.E. 1973. Distribution and differentiation of animals along the coast and in continental islands of the state of S. Paulo, Brazil - 1. Introduction to the area and problems. Pap. avulsos zool. 26(24):281-294

VITT, L.J. 1987. Communities. In Snakes: ecology and evolutionary biology (R.A. Seigel, J.T. Collins \& S.S. Novak, eds.). MacMillan Publishing Company, New York, p.335-365.

Data Received 13/03/08 Revised 30/06/08 Accepted 07/07/08 